\title{
REVIEW
}

\section{Potential effects of global climate change on National Fish Hatchery operations in the Pacific Northwest, USA}

\author{
Kyle C. Hanson*, Kenneth G. Ostrand \\ U. S. Fish and Wildlife Service, Abernathy Fish Technology Center, 1440 Abernathy Creek Rd., Longview, \\ Washington 98632, USA
}

\begin{abstract}
Global climate change is predicted to be a major force in altering ecosystem processes and animal behavior worldwide in the coming years. Currently, many Pacific salmon Oncorhynchus spp. stocks are imperiled due to harvest, habitat loss, and anthropogenic disturbance across much of their native range, and climate change has been predicted to have further negative effects on these species. Artificial propagation has been used by multiple resource agencies to conserve salmon populations and increase numbers in the Columbia River watershed, including the National Fish Hatchery (NFH) system in the Pacific Northwest, which annually produces more than 60 million juvenile Pacific salmonids. The species and populations that are supplemented through the NFH system, as well as operations at the NFHs themselves, will be affected by global climate change and forced to adapt. This review provides a preliminary summary of the potential effects of climate change on the NFH system in the Pacific Northwest, focusing on the topics that will be of most relevance to NFH operations. A series of proactive measures, which are in various stages of action, are outlined that should quantify climate change threats to the operations of specific NFHs and allow for flexibility in adjusting operations to continue to meet conservation and supplementation goals in the face of an uncertain future.
\end{abstract}

KEY WORDS: Climate change - Hatchery operations • Pacific salmon • Pacific Northwest . Columbia River

\section{INTRODUCTION}

Global climate change has been forecast to cause perturbations to ecosystem functions worldwide in the 21st century, possibly inducing a series of conservation issues for populations and species that are adapted to current local conditions (Markham 1996, Halpin 1997, Sala et al. 2000, McCarty 2001). Increasingly, researchers have correlated threats to species and populations with increases in global climate temperatures that have been seen in the 20th century (reviewed in McCarty 2001) and have theorized that these effects will be accelerated given current projections of climate change. Altered climatic conditions, especially increased temperatures, will induce ecosystem changes affecting populations including latitudinal (or altitudinal) changes in species distribution (Perry et al. 2005, Grebmeier et al. 2006, Brander 2007), collapses of populations that are unable to adapt to changing conditions (Pörtner \& Knust 2007), asynchrony of cues that lead to failure in large-scale animal migrations (McCarty 2001, Walther et al. 2002, Farrell et al. 2008), and altered timing of biological events that would historically, but no longer, coincide with seasonal changes in food availability (Wiltshire \& Manly 2004, Durant et al. 2007). Collectively, the conservation of many populations and species is threatened by climate change (Pörtner \& Farrell 2008). In 
particular, higher order species that have complex life histories and are adapted to historical environmental conditions are often viewed as uniquely threatened by climate change (Pörtner \& Farrell 2008).

Pacific salmon Oncorhynchus spp. share a set of complex life history characteristics (e.g. anadromy based on environmental cues, coldwater requirements based on physiology, large-scale migrations based on seasonal abundance of food resources, etc.) that especially predispose them to being threatened by climate change. Many salmon stocks are already imperiled due to harvest, habitat loss, and anthropogenic disturbance across much of their native range (Nehlsen et al. 1991). Multiple state, Tribal, and Federal agencies have used production hatcheries to mitigate declines in threatened stocks and to supplement population numbers throughout the range of these fish (Moring 1986, Lichatowich \& McIntyre 1987). The National Fish Hatchery (NFH) system in the Pacific Northwest, managed by the U.S. Fish and Wildlife Service, is comprised of 15 facilities (see Table 1; Fig. 1) that annually produce and release $>60$ million juvenile Pacific salmonids (U.S. Fish and Wildlife Service 2009). In the face of global climate change, the species and populations that are supplemented through the NFH system, as well as operations at the NFHs themselves, are likely to be stressed, and therefore will be forced to adapt.

This review provides a summary of the potential effects of global climate change on the NFH system in the Pacific Northwest; however, the discussion and recommendations for hatchery operations and management should also provide a framework thatcombined with the use of appropriate information related to local hatchery operations and improved regional climate models - can be applied to aquaculture systems worldwide after gathering appropriate data and development of regional models of future climate change scenarios. In this review, we discuss the predicted biological and ecological effects of climate change on salmon species and the potential alterations to hatchery facility operations. We provide recommendations for a set of proactive actions designed to assist in the refinement of existing scenarios of future climate change that provide specific information for NFH and regional managers. These recommendations are specifically aimed at internal hatchery processes, and help establish cause-and-effect relationships between performance, agency actions, and funding as they relate to climate change issues. Implementation of these recommendations, coupled with continued climate change forecasting and monitoring, will provide information to formulate facilityspecific operational plans that should help mitigate any potentially adverse effects.

\section{CLIMATE PREDICTIONS}

\section{General global predictions}

Global climate change is predicted to have multiple effects in various regions of the Pacific Northwest (Washington, Idaho, and Oregon). Various global climate models (GCMs) have been developed for the Intergovernmental Panel on Climate Change (IPCC) to form multiple projections of 21st century climatic conditions based upon variable current scenarios of greenhouse gas emissions, climate sensitivity, sea ice dynamics, etc. (Randall et al. 2007, Mote \& Salathé 2010). Compared to the average air temperature in the period 1970 to 1999 , most GCMs predict a $0.8^{\circ} \mathrm{C}$ increase in mean air temperature in the beginning of the 21st century with average increases of $1.1^{\circ} \mathrm{C}$ by the $2020 \mathrm{~s}$, $1.8^{\circ} \mathrm{C}$ by the $2040 \mathrm{~s}$, and $3.0^{\circ} \mathrm{C}$ by the $2080 \mathrm{~s}$ (Mote $\&$ Salathé 2010). However, the Pacific Northwest has a highly variable climate, and differing effects have been predicted based on regional differences in geographical climate zones. Salathé et al. (2010) generated 2 regional simulations based upon separate GCMs (the National Center for Atmospheric Research Community Climate System Model version 3 [CCSM3-WRF] and the Max Planck Institute, Hamburg, global model [ECHAM5-WRF]), which provide similar predictions for climate change in the period 2030 to 2059 for a

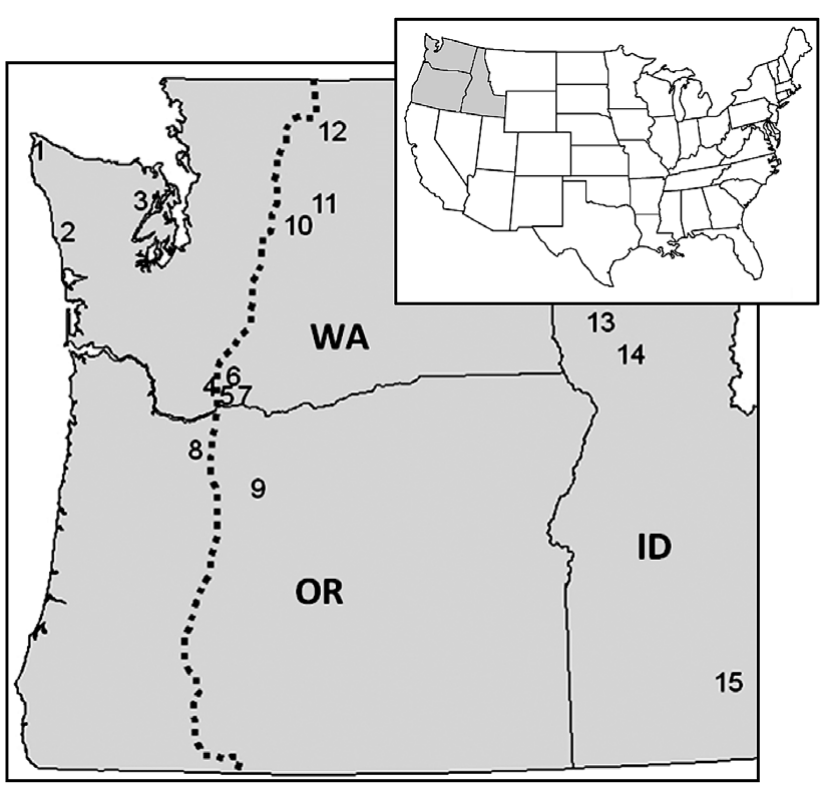

Fig. 1. National Fish Hatcheries (numbers) in the Pacific Northwest (WA: Washington; OR: Oregon; ID: Idaho). Dotted line: Cascade crest (major dividing line for climatic zones in the region). Hatcheries: 1, Makah; 2, Quinault; 3, Quilcene; 4, Carson; 5, Little White Salmon; 6, Willard; 7, Spring Creek; 8, Eagle Creek; 9, Warm Springs; 10, Leavenworth; 11, Entiat;

12, Winthrop; 13, Dworshak; 14, Kooskia; 15, Hagerman 
number of climatic variables, and will be discussed here by geographical region within the Pacific Northwest. Full details on the generation and validation of these regional climate change models can be found in Salathé et al. (2010).

\section{West of the Cascade Range and the Pacific coast}

Both regional climate change models predict warming in all seasons (when compared to current average air temperatures) in the areas to the west of the Cascade Range and along the coasts (Salathé et al. 2010). Increases in air temperature are forecasted to be the greatest in summer and spring (including increased frequency of heat waves; i.e. 3 or more consecutive days with a daily heat index of over $32^{\circ} \mathrm{C}$ ), while increased marine cloudiness in fall and winter may dampen temperature increases during those seasons (Salathé et al. 2010). Predictions of future precipitation levels vary by model with a majority of models predicting an annual increase in precipitation (Mote \& Salathé 2010), some models predicting a decrease relative to current observations (Leung et al. 2004). A strong seasonal pattern in altered precipitation relative to current levels is predicted for this area, as well as increases in the number of extreme precipitation events (daily precipitation exceeding the 20th century 95th percentile) (Salathé et al. 2010). Seasonal increases in precipitation have been predicted for fall, winter, and spring, and little change or a slight decline in precipitation has been predicted for summer (Salathé et al. 2010). The regional climate change models predict conflicting results for the spring season, with the CCSM3-WRF predicting a substantial decline in precipitation while the ECHAM5-WRF predicts increases in precipitation (Salathé et al. 2010).

\section{Cascade Range and Olympic mountains}

Both regional climate change models predict increases in mean air temperature in all seasons in both the Cascade and Olympic mountain ranges (Salathé et al. 2010). However, the models disagree as to the magnitude of warming in these areas, with the CCSM3WRF predicting greater regional increases (up to $3^{\circ} \mathrm{C}$ in summer) across this region and the ECHAM5-WRF predicting more modest $\left(1\right.$ to $2^{\circ} \mathrm{C}$ ) increases (Salathé et al. 2010). Warming in this area will also be affected by the interaction between snowpack and solar radiation since the loss of snowpack increases absorption of solar radiation, thereby contributing to accelerated warming (Leung et al. 2004, Salathé et al. 2010). Strong alterations to seasonal average precipitation have been predicted for both the Olympic and Cascade mountain ranges, with both regional models predicting that winter precipitation would decrease while autumn precipitation would increase (Salathé et al. 2010). The models produced variable predictions of either a substantial decline (CCSM3-WRF) or very little to no decline (ECHAM5-WRF) in precipitation levels for the summer, and opposite results of either decreased (CCSM3WRF) or increased (CCSM3-WRF) precipitation in spring (Salathé et al. 2010). Increases in the frequency of extreme precipitation events have also been predicted for these areas as a result of increased moisture in the air interacting with local topography (Salathé et al. 2010).

Ultimately, these predicted changes in temperature and precipitation have drastic consequences for snowpack in mountainous terrain. Following the trend of recent years (Mote 2003, Mote et al. 2004, Knowles et al. 2006, Pierce et al. 2008), alpine snowpack is predicted to decrease dramatically as air temperatures increase at high elevations (Salathé et al. 2010). Increased regional warming coupled with decreases in winter precipitation would hasten the declines in snowpack (Salathé et al. 2010). As a result, spring snowmelt will occur earlier during the season leading to altered timing of spring freshet in streams and river runoff levels (Mote 2003, Mote et al. 2004). Evidence for this process has been observed as peak flows have progressively moved earlier into the spring season across the last 50 yr (Stewart et al. 2005, Hidalgo et al. 2009). Quite obviously, streams where snowmelt provides the dominant source of flow and that depend on snowpack as a reservoir of freshwater will be most affected (Mote 2003, Mote et al. 2004, Knowles et al. 2006, Pierce et al. 2008).

\section{East of the Cascade Range}

Mean air temperature is predicted to significantly increase across all seasons to the east of the Cascade mountains by both regional climate change models, with the CCSM3-WRF model consistently predicting greater increase than the ECHAM5-WRF model (Salathé et al. 2010). The CCSM3-WRF model predicts the greatest seasonal increase of up to $3^{\circ} \mathrm{C}$ in the summer, while the ECHAM5-WRF model predicts a lower increase of only 1.5 to $2.5^{\circ} \mathrm{C}$ (Salathé et al. 2010). The frequency of heat waves is predicted to increase substantially, especially in southwest Washington (Salathé et al. 2010). Increases of $>1^{\circ} \mathrm{C}$ are predicted by both models for the rest of the seasons (Salathé et al. 2010). Both models predict increases in winter and fall precipitation with slight or no increases in summer precipitation (Salathé et al. 2010). The regional climate change 
models predict conflicting results for the spring season with the CCSM3-WRF predicting a substantial decrease in precipitation while the ECHAM5-WRF predicts increased precipitation (Salathé et al. 2010). The frequency of extreme precipitation events will vary, based upon local geographical conditions, with a decrease in the lee of the Cascade Mountains and an overall increase across the rest of the region (Leung et al. 2004, Salathé et al. 2010).

\section{IN-RIVER BIOLOGICAL AND ECOLOGICAL EFFECTS}

The biological and ecological ramifications of climate change on wild salmon stocks have been discussed often in the literature in recent years with a particular emphasis placed on modeling the effects of climate change on salmon populations at the regional scale (e.g. Scheuerell \& Williams 2005, Crozier et al. 2008a,b, Bryant 2009). Both observational and experimental studies of Pacific salmon have focused on the effects of temperature on a host of biological systems across all life history stages. As such, we will limit our discussion of the biological and ecological effects of climate change here to those that are most likely to be of concern to NFH stocks and wild stocks that are supplemented by NFH production facilities. While our discussion focuses on the freshwater phase of the life history of Pacific salmon, it is important to note that climate change impacts on ocean conditions will also play an important role in constraining the future productivity of salmon stocks (Fabry et al. 2008).

Multiple studies have focused on the effect of rising water temperatures on adult salmon spawning migrations. Across the terminal portion of the migration, fish face thermal stress in the freshwater environment that can lead to delays in migration and/or premature mortality and migration failure (Salinger \& Anderson 2006). During aerobic swimming that is required for migration, aerobic scope for activity (the difference between basal and maximum metabolic rates), which constrains sustained and maximum swimming speeds, has been shown to have an optimum temperature in Pacific salmonids (Lee et al. 2003, MacNutt et al. 2006). Temperatures above this optimum cause inadequate blood flow to tissues resulting in anaerobic respiration and, ultimately, energy depletion, physiological dysfunction, and premature mortality prior to salmon reaching their spawning grounds (Pörtner \& Knust 2007, Clark et al. 2008, Farrell et al. 2008). Adult migration timing has evolved in response to the interplay between thermal optima and historical temperature regimes experienced by stocks during spawning migrations (Hodgson \& Quinn 2002). However, climate change and anthropogenic alterations to habitat have caused increases in river temperature at a rapid rate in recent years. Changes in migration timing of adult salmon have not kept pace with changes in river temperature (Quinn \& Adams 1996), leading to the possibility that fish will experience above-optimal temperatures causing large-scale mortality due to physiological mal-adaptation to current conditions (Quinn \& Adams 1996, Rand et al. 2006, Farrell et al. 2008, Keefer et al. 2008b). As a side effect, migrating adults are forced to seek refuge in cold water tributaries to avoid high mainstem temperatures (Keefer et al. 2008a,b), artificially concentrating salmon and potentially leading to increased direct mortality from harvest as well as delayed mortality from handling stress. Rising river temperatures lead to increased infection rates and disease progression in the freshwater stage of migration (Udey et al. 1975, Wedemeyer 1996, Marcogliese 2001, Kocan et al. 2009) which can also impact adult survival to spawning grounds or hatchery facilities. At extreme levels, major mortality due to complications resulting from thermal stress may cause stock specific declines in the number of adult fish that return to NFH facilities, thereby limiting the availability of broodstock.

Juvenile salmon released from NFHs may also face challenges associated with thermal stress. Emigrating smolts may also face stress and physiological dysfunction due to increased river temperatures that could result in mortality prior to reaching the ocean, though size-based effects of thermal stress may alter the absolute temperature at which a juvenile salmon face physiological dysfunction (Clark et al. 2008). Increases in stress hormone concentrations (principally blood cortisol) related to thermal stress lead to decreases in immune function and an increase in infection- and disease-related mortality (Barton \& Iwama 1991, Barton 2002). Decreased aerobic scope could directly lead to decreased swimming performance that is vital to surviving predator/prey interactions, navigating complex river flows, and avoidance of any hydropower infrastructure along the migration route (Lee et al. 2003, MacNutt et al. 2006). The interplay of changing hydrological and thermal patterns in major rivers and the influence of hydropower infrastructure may lead to alteration of behaviorally optimal emigration timing (which also typically coincide with juvenile bypass practices at hydropower facilities) related to high smolt to adult survival (Beckman et al. 2000, Scheuerell et al. 2009). Finally, juvenile salmonids may encounter a drastically different community structure in the mainstem and estuaries as thermal habitats continue to change allowing for the invasion and establishment of different year round resident species. Populations of warmwater piscivorous species such as black bass Micropterus spp. and northern 
pikeminnow Ptychocheilus oregonensis that are already established in large rivers in the Pacific Northwest, but are largely limited due to thermal constraints on habitat selection, may increase in numbers and expand in range (Jackson et al. 2001). Their expansion may lead to increased predation on both wild and hatchery juvenile salmonids (Crozier et al. 2008b, Scheuerell et al. 2009). Increased juvenile mortality associated with any one of these effects can lead to decreasing adult returns, further hampering $\mathrm{NFH}$ efforts.

Wild populations will likewise be affected by climate change at a number of life history stages. Salmon smolt production and survival has been correlated with climatic conditions during freshwater rearing (Lawson et al. 2004), and alterations to key environmental variables such as temperature and timing of forage availability have been predicted to have deleterious effects on juvenile salmon (Bryant 2009). Rearing habitat that provides suitable conditions for optimal development of eggs and juvenile fish will be limited by increasing temperatures in streams and rivers as well as the potential for dewatering in areas of decreased snowpack or precipitation, or flooding due to increased ocean levels in coastal areas (Mohseni et al. 1999, Crozier et al. 2008b, Bryant 2009, Mantua et al. 2010). Changing instream temperatures can lead to alteration of the environmental processes and cues associated with hatching (Beer \& Anderson 2001), smoltification (Hoar 1988), and emigration (Beckman et al. 2000) and an eventual decoupling of environmental and biological cues.

Emigration timing for juvenile salmon is a function of growth rate, which is at least partially related to temperature in rearing habitats, and environmental cues such as photoperiod (Hoar 1988, Handeland et al. 2003, Ban et al. 2007). Populations in areas with colder instream flows typically grow at a slower rate and emigrate at an older age than conspecifics in warmer areas (Taylor 1990, Unwin et al. 2000). Increases in temperature predicted by climate change models have the potential to increase instream water temperatures leading to increased growth if sufficient forage is available (Boughton et al. 2007), potentially directly decreasing freshwater rearing time and accelerating emigration for juvenile salmon. Rearing and residency times that are highly correlated with regional hydrologic regimes that determine instream temperatures (i.e. snowmelt or rainwater dominated stream flows) may indirectly change as low elevation snowpack has been predicted to decline (Mote et al. 2003, Mantua et al. 2010), leading to alterations in optimal emigration timing in relation to flow regime. However, environmental cues for smoltification such as photoperiod will remain static regardless of temperature changes, lead- ing to a disconnect between fish condition, the onset of the physiological process of smoltification, and optimal local hydrology for emigration.

Climate change is predicted to drive species ranges toward the poles (Parmesan \& Yohe 2003), thereby impacting populations at southern latitudes disproportionally. This could lead to further declines in salmon populations at low latitudes and the need for higher levels of mitigation production in the short term. However, over longer time periods, if climate change were to continue unabated and the thermal habitat in lower latitudes became unsuitable for wild and hatchery fish survival, salmon production may no longer be required as target populations and associated fisheries may cease to exist. At the same time, salmon populations at northern latitudes could benefit from global climate change through increased access to thermally suitable habitat for spawning and rearing (Parmesan \& Yohe 2003). Increased nearshore ocean temperatures may also increase primary ocean productivity leading to improved salmon survivability and production, though this process will be affected by interactions with largescale climatic oscillations occurring over the Pacific Ocean (Beamish 1993, Beamish \& Bouillon 1993, Finney et al. 2000).

While many of the predictions of the effects of climate change upon salmon populations paint a bleak future for many species and stocks, it must be noted that these effects will be highly variable dependent on a number of factors. Climate change will ultimately interact with multiple environmental and biological processes that may result in various negative, neutral, or positive effects on populations across the range of the species in question (Bryant 2009). Predictions of the evolution of an organism in response to climate change are often coupled with uncertainty about potentially mitigating factors (Holt 1990) such as differential selection across the life history of the animal (Crozier et al. 2008a) resulting in changes in phenotypic and genetic diversity within and among populations (Beechie et al. 2006, Mantua et al. 2010). Given this framework, it is unrealistic to think that Pacific salmon are doomed by climate change (Bryant 2009). However, as many of the predicted deleterious effects of climate change will impose multiple stressors on salmon populations, the overall outlook for a number of populations is more than likely not favorable and a proactive and conservative management approach is necessary to conserve both wild and hatchery populations. While the ultimate effects of climate change on wild populations may be difficult to predict, it may be safe to assume that managers will continue to use hatchery supplementation to mitigate any large-scale losses of wild populations caused by the processes noted above. 
Table 1. Classification of likely climate change effects on specific National Fish Hatcheries (NFH) in the Pacific Northwest. $\mathrm{X}$ : facility predicted to experience effect, based on current climate change models. Season (spring, summer, fall, winter): time when a facility is predicted to be affected. Blank: facility is unlikely to be seriously affected

\begin{tabular}{|c|c|c|c|c|c|}
\hline NFH facility & $\begin{array}{l}\text { Increasing air } \\
\text { temperature }\end{array}$ & $\begin{array}{l}\text { Decreasing } \\
\text { rainfall }\end{array}$ & $\begin{array}{l}\text { Increasing } \\
\text { rainfall }\end{array}$ & $\begin{array}{l}\text { Seawater } \\
\text { intrusion }\end{array}$ & $\begin{array}{c}\text { Altered hydro } \\
\text { logical cycle }\end{array}$ \\
\hline \multicolumn{6}{|l|}{ Idaho } \\
\hline Dworshak & $\mathrm{X}$ & Spring & Fall, winter & & $\mathrm{X}$ \\
\hline Hagerman & $\mathrm{X}$ & Spring, summer & Fall & & $\mathrm{X}$ \\
\hline Kooskia & $\mathrm{X}$ & Spring & Fall, winter & & $\mathrm{X}$ \\
\hline \multicolumn{6}{|l|}{ Oregon } \\
\hline Eagle Creek & $\mathrm{X}$ & & & & $\mathrm{X}$ \\
\hline Warm Springs & $\mathrm{X}$ & Winter, summer & Fall & & $\mathrm{X}$ \\
\hline \multicolumn{6}{|l|}{ Washington } \\
\hline Carson & $\mathrm{X}$ & Winter, summer & Fall & & $\mathrm{X}$ \\
\hline Entiat & $\mathrm{X}$ & Winter, summer & Fall & & $\mathrm{X}$ \\
\hline Leavenworth NFH Complex & $\mathrm{X}$ & Winter, summer & Fall & & $\mathrm{X}$ \\
\hline Little White Salmon & $\mathrm{X}$ & Winter, summer & Fall & & $\mathrm{X}$ \\
\hline Makah & $\mathrm{X}$ & $\mathrm{X}$ & & $\mathrm{X}$ & $\mathrm{X}$ \\
\hline Quilcene & $\mathrm{X}$ & $\mathrm{X}$ & & $\mathrm{X}$ & \\
\hline Quinault & $\mathrm{X}$ & $\mathrm{X}$ & & & \\
\hline Spring Creek & $\mathrm{X}$ & Winter, summer & Fall & & $\mathrm{X}$ \\
\hline Willard & $\mathrm{X}$ & Winter, summer & Fall & & $\mathrm{X}$ \\
\hline Winthrop & $\mathrm{X}$ & & & & \\
\hline
\end{tabular}

\section{HATCHERY OPERATIONS}

Beyond the general biological effects mentioned above, hatchery operations may be affected by a number of specific issues (Table 1) that are related to the realities of production of a large number of fish at high densities. A number of future climatic scenarios would drastically affect water availability and usage in the Pacific Northwest. Altered hydrological regimes will have numerous effects on hatchery operations dependent on these water sources as well as the focal streams in which fish are released. Hatcheries will also face ongoing challenges as air and water temperatures increase during the rearing cycle of Pacific salmonids.

\section{Water resources}

As the general climate change predictions for the Pacific Northwest include warmer temperatures in all seasons and seasonal changes in precipitation (decreasing in summers, increasing in winters) (Mote et al. 2003, Salathé et al. 2010), stream and river hydrology across the region will be altered, potentially affecting facilities that draw water from local surface flows and underground aquifers. Collectively, these changes may be most dramatic in smaller watersheds that have no artificial reservoirs to equitably distribute water throughout the year (Mote et al. 2003). Increased winter temperatures coupled with increased winter rainfall will prevent the accumulation of snowpack and lead to high surface flows and potential flooding during the fall and winter (Mote et al. 2003). Additionally, the loss of the freshwater reservoir of the snowpack coupled with higher air temperatures and decreased precipitation during summer months will lead to decreased summer flows and increased water temperatures (Mote et al. 2003). Facilities that draw water from streams will likely face seasonal variations in surface flow that may limit water availability in the summer months and force alterations to rearing densities and schedules. In contrast, facilities that divert flow from larger rivers with multiple impoundments will likely be spared problems with access to sufficient water as artificial reservoirs will retain precipitation from the winter that can be distributed during the drier summer, though increases in water temperatures within impoundments will still be a major factor that can alter rearing densities and schedules. Coastal areas will have additional concerns in relation to water collection. Sea levels are predicted to rise due to a combination of expansion of sea water volume at higher temperatures and increases in water levels due to sea ice and glacier melting (Mote et al. 2008, Huppert et al. 2009). Increased ocean levels may in turn lead to localized flooding in coastal areas and erosion of beaches and shoreline bluffs (Huppert et al. 2009). Saltwater may intrude into aquifers that are close to the ocean, though this is only predicted to occur in a narrow band near shorelines (Barlow 2003, Huppert et al. 2009).

Climate change will likely generate increased disputes over water rights in the Pacific Northwest. Freshwater is managed in the area to provide optimal flows for power generation, navigation, diversion for irrigation, human use in developed areas, and to provide suitable flows for the conservation of threatened and 
endangered fish species (Wood et al. 1997, Payne et al. 2004, Hamlet et al. 2010). The impacts of climate change will be especially dramatic on agricultural operations located in the rain shadow of the Cascade Range as these areas are predicted to see both an increase in air temperature and a decrease in precipitation. Alone, increases in air temperature predicted by climate change models will lead to drying of the soil column during the growing season (Hamlet \& Lettenmaier 1999, Vano et al. 2010) which will be exacerbated by decreases in summer precipitation. Functionally, more water will need to be removed from river systems to be used in irrigation to compensate for dried soil at the specific times of year when stream flows will be lowest. Altered reservoir cycling and recharge due to loss of snowpack will also lead to continued conflicts between the water requirements for hydropower generation and instream flow alterations available for non-turbine (i.e. spill, bypass systems) passage of threatened fish species (Payne et al. 2004). Water will also be diverted for continued development in urban areas both for consumption and to satisfy increasing energy demands (Hamlet et al. 2010). Waste water discharge from facilities may be impacted by regulatory alterations in the face of reduced flows and changing biological processes within water treatment areas (e.g. settling basins). As there is a finite amount of water that can be removed from a particular stream under current guidelines, it is safe to assume that future water rights will be a contentious issue and all users (including $\mathrm{NFH}$ facilities completely dependent on diverted freshwater) will be affected.

Hatchery managers may also be increasingly challenged to alter salmon rearing techniques and timing to match hydrological changes in the focal rivers where fish are released. In streams that are subject to an earlier freshet and lower stream flows during the summer months, salmonid utilization and emigration patterns may be affected (Beckman et al. 2000). Species that typically migrate during spring freshet or are highly susceptible to increased temperatures and low flows during summer may exhibit changes in life history characteristics such as emigration timing (Crozier et al. 2008a,b). Correspondingly, hatchery managers may need to adjust release schedules of fish from production facilities to mimic the emigration period of wild fish. However, alterations to juvenile migration timing may lead to unforeseen complications if emigration does not coincide with seasonally abundant food resources in the estuarine and offshore environment (Bryant 2009). Monitoring of the ecology of target wild populations coupled with maintaining the flexibility to alter hatchery operations rapidly will be required to fulfill the mission of the U.S. Fish and Wildlife Service (FWS) (Battin et al. 2007).

\section{Within-facility biological issues during the rearing period}

Increasing air temperatures and decreased flows during summer months may significantly affect NFHs' diverted water supplies. Carrying capacities within facilities will be greatly affected as oxygen saturation levels decline with increased water temperatures (Piper et al. 1982). As growth and developmental rates in fish positively respond to increases in water temperatures (Beamish 1970, Brett 1971, Fry 1971, Hazel 1993), hatchery managers may need to change rearing techniques to meet current size-at-release targets as salmon growth rates will increase in warmer water temperatures. Faced with increased growth rates, managers will need to decide to either decrease production numbers to account for the increased biomass (release fewer, larger fish at a greater cost per individual) or retard fish growth by decreasing ration levels (potentially impacting fish condition and health). Drastic increases in water temperature that exceed lethal temperatures for salmonids may also simply make some water sources unsuitable for production facilities. Though water temperatures at most of the Pacific Northwest NFHs may not exceed lethal limits for juvenile salmon, increased water temperatures coupled with the multiple stressors that are already faced by salmon in production facilities (e.g. crowding, handling, etc.) may contribute to increases in mortality (Farrell et al. 2008, Farrell 2009). The prevalence and magnitude of common fish pathogen and parasite infections may also increase, leading to increased mortality rates (Udey et al. 1975, Wedemeyer 1996, Marcogliese 2001, Kocan et al. 2009). To meet production goals while contending with increased water temperatures and pathogen prevalence as well as decreased oxygen saturation and carrying capacities, FWS staff must be proactive in identifying trends, measuring and monitoring salmon performance, and actively targeting program inefficiencies to avoid direct and ancillary effects of changing temperature regimes.

As it has been predicted that wild populations will likely suffer in the face of climate change, hatcheries will also need to continue to monitor the genetic and phenotypic similarities between wild and hatchery origin fish. Increasing temperatures and altered hydrology in natal streams will induce new selection pressures on the life history characteristics of wild fishes (Battin et al. 2007, Crozier et al. 2008a,b), potentially altering the genetic structure of populations that are the focus of supplementation by NFHs (Beechie et al. 2006, Mantua et al. 2010). If the fish released from an $\mathrm{NFH}$ are intended for the conservation of a wild stock, hatchery and wild populations should remain genetically similar to avoid outbreeding depression leading to reduced fitness of the wild population, and new guide- 
lines may be needed for the management of integrated or segregated populations within facilities (Waples 1991, Campton 1995, Araki et al. 2008, 2009). However, as predictions of species and populations responses to climate change are likely impossible, continued monitoring will be needed to reassess genetic similarity between hatchery and wild fish and inform broodstock selection decisions.

\section{FACILITY-SPECIFIC EXAMPLES}

We have chosen 2 NFHs in disparate areas of the Pacific Northwest to serve as examples of the differing predicted effects by climate change. Climate change predictions are based upon the regional climate change models (CCSM3-WRF and ECHAM5-WRF) generated in Salathé et al. (2010) for the years 2030 to 2059 when compared to the years 1970 to 1999.

\section{Makah NFH, Neah Bay, Washington}

This facility will likely face moderate issues related to temperature and precipitation changes due to predicted climate change, and also has the potential to be affected by coastal phenomena related to increases in sea water levels. The predicted local climate change impacts at this facility include increased air temperatures in all seasons (approximately: winter +1 to $2^{\circ} \mathrm{C}$, spring +1 to $2^{\circ} \mathrm{C}$, summer +1.5 to $2.5^{\circ} \mathrm{C}$, fall +1.5 to $2.5^{\circ} \mathrm{C}$ ) and alterations to local precipitation. Both predictive climate change models indicate that there will be increases in rainfall during fall (+20 to $55 \mathrm{~mm}$ ) and no change or a slight decrease in rainfall during winter ( -20 to $0 \mathrm{~mm}$ ) and summer ( -10 to $0 \mathrm{~mm})$. For spring, the CCSM3-WRF model predicts a decrease in precipitation ( -30 to $40 \mathrm{~mm}$ ), whereas the ECHAM5-WWRF model predicts an increase (+20 to $40 \mathrm{~mm}$ ). Snowpack is also predicted to decrease at elevations in the Olympic Mountains which, when combined with altered seasonal precipitation, has the potential to affect the hydrological regime of streams feeding the Sooes and Wa'atch Rivers. Migration timing of both juvenile and adult salmon to these watersheds should be monitored to ensure that NFH activities correctly coincide with timing of natural migrations. The facility is located inland ( 8 miles SW of Neah Bay) and is less likely to be directly affected by shoreline erosion and rising sea levels, though water sources derived from local aquifers should be monitored for salinity/conductivity as a sign of contamination by seawater intrusion into the water table. Total flow within the water supply should also be monitored to determine aquifer recharge rates resulting from diminished snowpack and precipitation.

\section{Hagerman NFH, Hagerman, Idaho}

This facility is likely to face serious issues related to increased temperatures, decreased precipitation and snow pack, and associated water availability due to predicted climate change. Air temperatures in this area are predicted to increase markedly in all seasons (approximately: winter +1.5 to $2.5^{\circ} \mathrm{C}$, spring +1.5 to $2^{\circ} \mathrm{C}$, summer +2 to $3^{\circ} \mathrm{C}$, fall +2 to $2.5^{\circ} \mathrm{C}$ ). Both predictive climate change models indicate that there will be slight increases in rainfall during fall (+0 to $10 \mathrm{~mm}$ ) and little change in rainfall during winter $(+0$ to $5 \mathrm{~mm})$ and summer (+0 to $10 \mathrm{~mm}$ ). For spring, the CCSM3WRF model predicts no changes in precipitation, whereas the ECHAM5-WWRF model predicts a slight increase (+20 to $40 \mathrm{~mm}$ ). Higher local air temperatures coupled with decreased seasonal rainfall and decreased regional snow pack will likely lead to greater demand for water from local aquifers for irrigation and consumptive use in local communities. This may affect local aquifer recharge rate potentially leading to serious water rights conflicts. Abiotic conditions such as temperature and stream flow regimes will also be affected leading to potential changes in salmon migration behavior that should be monitored to ensure that NFH practices correctly mimic natural behavior. Increased air temperatures may also lead to increased water temperatures within the facility requiring the use of a water cooling system to prevent deleterious biological effects of high temperatures (i.e. increased disease prevalence, increased temperature related stress, associated mortality).

\section{MANAGEMENT RECOMMENDATIONS}

A comprehensive set of actions can be instituted to determine the vulnerability of the NFH system in the Pacific Northwest to the effects of global climate change. First, a set of future climate scenarios representing a range of uncertainty should be applied to provide multiple sets of predictions for individual NFHs to elucidate the unique potential challenges that will arise at each facility. Downscaled models need to be developed that can integrate future climate scenarios with life history characteristics of fish stocks to determine the biological, logistical, and monetary impacts to FWS facilities and conservation goals.

Second, programs in monitoring and evaluation of biotic and abiotic factors at each NFH, state, and federal resource agency need to be continued and potentially expanded. Migration timing of adults and juveniles from both wild and hatchery populations should be monitored to reveal long-term trends and potential changes resulting from climate change. Further re- 
search should also focus on evaluating innovative techniques for detecting and monitoring aquatic invasive species range expansion, invasion, and establishment. Finally, fish pathogen presence, range expansion, and resistance to approved treatment options should be documented to aid in diagnosis and treatment of pathogens that may spread as stress imparted by climate change alters susceptibility of fish stocks.

Third, we advocate that NFHs expand record keeping to include an easily searchable database of information including, but not limited to, water source temperatures and availability, biological metrics of wild populations, and genetic sampling of wild and hatchery populations. All NFH facilities should review their current water rights and associated state and federal statutes, and document and list primary sources of water and the time of year, volume, and flows required to meet current production goals. Specifically, spring, well, and surface water flows and recharge durations need to be determined with a high degree of accuracy using accepted methods so that this data is suitable for use in potential water rights adjudication proceedings. Water usage monitoring can be implemented through the establishment of fixed sites within wells, springs, and intake and release streams to track monthly water levels, use, temperature, and salinity/conductivity. If facilities will likely suffer from declining water resources, water re-circulation systems should be investigated. At NFHs where water source temperatures may be predicted to exceed sublethal and lethal tolerances of focal species, current production goals need to be evaluated and contingency production plans should be developed that identify production levels at variable water temperatures and flow rates. These facilities should also investigate the possibility of accessing cooler water from other sources, such as deep wells, that will not be affected by changes in surface water temperature. If this is not possible, facilities should investigate the installation of equipment to cool surface water or flow-through systems that cool water passively such as deep-well injection technology. These evaluations must include the financial and $\mathrm{CO}_{2}$ costs associated with water cooling systems for facilities that may not have access to water resources of an appropriate temperature to maintain production. Biotic data, such as disease outbreak incidence and intensity, should be collected throughout annual production cycles. Finally, continued research into the densityand handling-dependent stressors associated with hatchery practices, and production goals should focus on integrating temperature data to be used to modify hatchery practices, if necessary. This information will prove to be invaluable in establishing a baseline by which future changes can be compared to determine appropriate actions to mitigate the effects of climate change. Climate change components can be easily added to the Hatchery Genetic Management Plans, or similar management documents of each facility, to ensure that standardized monitoring plans for collection of comparative data are implemented at all NFHs. Coupled with continued monitoring of wild populations, 'Hatchery Climate Change Plans' could be a powerful tool allowing managers to adjust operations rapidly and avoid later 'crisis' situations.

\section{CONCLUSIONS}

Even though future climate scenarios will always carry substantial uncertainties, global climate change has been forecasted to have manifold negative consequences with regards to environmental variables affecting both wild and hatchery populations of salmon, including hatchery populations designed to conserve these species. Proactive measures can be undertaken currently that will allow for advanced warning of potential climate change threats to the operations of NFHs and allow for flexibility in adjusting operations to continue to meet the mission of the U.S. Fish and Wildlife Service in the face of an uncertain future. Integration of the NFH system with agency action plans such as Landscape Conservation Cooperative's that are focused on studying the effects of climate change will be required for the implementation of comprehensive plans to mitigate the effects of climate change and will serve as a point of contact for the cooperation of all stakeholders of fisheries resources in the region including federal, state, and tribal agencies. The recommendations set forth in this review, some of which are already being conducted, should enable managers to document and respond to changes associated with climate change in a timely manner that will allow for the conservation and continued existence of threatened and endangered salmon stocks within the Pacific Northwest.

Acknowledgements. We thank L. Marchant and S. Doulos for their review comments. The findings and conclusions in this paper are those of the authors and do not necessarily represent the views of the US Fish and Wildlife Service.

\section{LITERATURE CITED}

Araki H, Berejikian BA, Ford MJ, Blouin MS (2008) Fitness of hatchery-reared salmonids in the wild. Evol Appl 1: 342-355

Araki H, Cooper B, Blouin MS (2009) Carry-over effect of captive breeding reduces reproductive fitness of wild-born descendents in the wild. Biol Lett 5:621-624

Ban M, Hironori A, Akihisi U (2007) Effects of long-day on gill $\mathrm{Na}^{+}, \mathrm{K}^{+}$-ATPase gene expression and the development of 
seawater tolerance in sockeye salmon. Aquaculture 273: 218-226

Barlow PM (2003) Ground water in freshwater-saltwater environments of the Atlantic coast. US Dept Interior and US Geol Survey Circ 1262:1-113

Barton BA (2002) Stress in fishes: a diversity of responses with particular reference to changes in circulating corticosteroids. Integr Comp Biol 42:517-525

Barton BA, Iwama GK (1991) Physiological changes in fish from stress in aquaculture with emphasis on the response and effects of corticosteroids. Annu Rev Fish Dis 1:3-26

Battin J, Wiley MW, Ruckelshaus MH, Palmer RN, Korb E, Bartz KK, Imaki H (2007) Projected impacts of climate change on salmon habitat restoration. Proc Natl Acad Sci USA 104:6720-6725

Beamish FWH (1970) Oxygen consumption of largemouth bass, Micropterus salmoides, in relation to swimming speed and temperature. Can J Zool 48:1221-1228

Beamish RJ (1993) Climate and exceptional fish production off the west-coast of North-America. Can J Fish Aquat Sci 50:2270-2291

Beamish RJ, Bouillon DR (1993) Pacific salmon production trends in relation to climate. Can J Fish Aquat Sci 50: 1002-1016

Beckman BR, Larsen DA, Sharpe C, Lee-Pawlak B, Schreck CB, Dickhoff WW (2000) Physiological status of naturally reared juvenile spring Chinook salmon in the Yakima River: seasonal dynamics and changes associated with smolting. Trans Am Fish Soc 129:727-753

Beechie T, Buhle E, Ruckelshaus M, Fullerton A, Holsinger L (2006) Hydrologic regime and the conservation of salmon life history diversity. Biol Conserv 130:560-572

Beer WN, Anderson JJ (2001) Effect of spawning day and temperature on salmon emergence: interpretations of a growth model for Methow River Chinook. Can J Fish Aquat Sci 58:943-949

Boughton DA, Gibson M, Yedor R, Kelley E (2007) Stream temperature and the potential growth and survival of juvenile Oncorhynchus mykiss in a southern California Creek. Freshw Biol 52:1353-1364

Brander KM (2007) Global fish production and climate change. Proc Natl Acad Sci USA 104:19709-19714

Brett JR (1971) Energetic responses of salmon to temperature: a study of same thermal relations in the physiology and freshwater ecology of sockeye salmon (Oncorhynchus nerka). Am Zool 11:99-113

Bryant MD (2009) Global climate change and potential effects on Pacific salmonids in freshwater ecosystems of southeast Alaska. Clim Change 95:169-193

Campton DE (1995) Genetic effects of hatchery fish on wild populations of Pacific salmon and steelhead: What do we really know? Am Fish Soc Symp 15:337-353

Clark TD, Sandblom E, Cox GK, Hinch SG, Farrell AP (2008) Circulatory limits to oxygen supply during an acute temperature increase in the Chinook salmon (Oncorhynchus tshawytscha). Am J Physiol 295:R1631-R1639

Crozier LG, Hendry AP, Lawson PW, Quinn TP and others (2008a) Potential responses to climate change in organisms with complex life histories: evolution and plasticity in Pacific salmon. Evol Appl 1:252-270

Crozier LG, Zabel RW, Hamlett AF (2008b) Predicting differential effects of climate change at the population level with life-cycle models of spring Chinook salmon. Glob Change Biol 14:236-249

$>$ Durant JM, Hjermann DØ, Ottersen G, Stenseth NC (2007) Climate and the match or mismatch between predator re- quirements and resource availability. Clim Res 33:271-283

Fabry VJ, Seibel BA, Feely RA, Orr JC (2008) Impacts of ocean acidification on marine fauna and ecosystem processes. ICES J Mar Sci 65:414-432

> Farrell AP (2009) Environment, antecedents, and climate change: lessons from the temperature physiology and river migration of salmonids. J Exp Biol 212:3771-3780

Farrell AP, Hinch SG, Cooke SJ, Patterson DA, Crossin GT, Lapointe M, Mathes MT (2008) Pacific salmon in hot water: applying aerobic scope models and biotelemetry to predict the success of spawning migrations. Physiol Biochem Zool 81:697-708

Finney BP, Gregory-Eaves I, Sweetman J, Douglas MSV, Smol JP (2000) Impacts of climatic change and fishing on Pacific salmon abundance over the past 300 years. Science 290:795-799

Fry FEJ (1971) The effect of environmental factors on the physiology of fish. In: Hoar WS, Randall DJ (eds) Fish physiology, Vol 6. Academic Press, New York, NY, p 1-98

Grebmeier JM, Overland JE, Moore SE, Farley EV and others (2006) A major ecosystem shift in the northern Bering Sea. Science 311:1461-1464

Halpin PN (1997) Global climate change and natural-area protection: management responses and research directions. Ecol Appl 7:828-843

> Hamlet AF, Lettenmaier DP (1999) Effects of climate change on hydrology and water resources objectives in the Columbia River Basin. J Am Water Resour Assoc 35: 1597-1623

Hamlet AF, Lee SY, Mickelson KEB, Elsner MM (2010) Effects of projected climate change on energy supply and demand in the Pacific Northwest and Washington state. Clim Change 102:103-128

> Handeland SO, Porter M, Björnsson BT, Stefansson SO (2003) Osmoregulation and growth in a wild and a selected strain of Atlantic salmon smolts on two photoperiod regimes. Aquaculture 222:29-43

Hazel JR (1993) Thermal biology. In: Evans DH (ed) The physiology of fishes. CRC Press, Boca Raton, FL, p 427-467

> Hidalgo HG, Das T, Dettinger MD, Cayan DR and others (2009) Detection and attribution of streamflow timing changes to climate change in the Western United States. Clim 22:3838-3855

Hoar WS (1988) The physiology of smolting salmonids. In: Hoar WS, Randall DJ (eds) Fish physiology, Vol 11. Academic Press, New York, NY, p 275-343

Hodgson S, Quinn TP (2002) The timing of adult sockeye salmon migration into freshwater: adaptations by populations to prevailing thermal regimes. Can J Zool 80: $542-555$

Holt RD (1990) The microevolution consequences of climate change. Trends Ecol Evol 5:311-315

Huppert DD, Moore A, Dyson K (2009) Impacts of climate change on the coasts of Washington State. In: Littell JS, McGuire Elsner M, Whitely Binder LC, Snover AK (eds) The Washington climate change impacts assessment: evaluating Washington's future in a changing climate. Climate Impacts Group, University of Washington, Seattle, WA, p 285-309

> Jackson DA, Peres-Neto PR, Olden JD (2001) What controls who is where in freshwater fish communities - the roles of biotic, abiotic, and spatial factors? Can J Fish Aquat Sci 58:157-170

> Keefer ML, Caudill CC, Peery CA, Boggs CT (2008a) Nondirect homing behaviours by adult Chinook salmon in a large, multi-stock river system. J Fish Biol 72:27-44 
Keefer ML, Peery CA, Heinrich MJ (2008b) Temperaturemediated en route migration mortality and travel rates of endangered Snake River sockeye salmon. Ecol Freshwat Fish 17:136-145

Knowles N, Dettinger MD, Cayan DR (2006) Trends in snowfall versus rainfall in the Western United States. J Clim 19:4545-4559

Kocan R, Hershberger P, Sanders G, Winton J (2009) Effects of temperature on disease progression and swimming stamina in Ichthyophonus-infected rainbow trout, Oncorhynchus mykiss (Walbaum). J Fish Dis 32:835-843

Lawson PW, Logerwell EA, Mantua NJ, Francis RC, Agostini VN (2004) Environmental factors influencing freshwater survival and smolt production in Pacific Northwest Coho salmon (Oncorhynchus kisutch). Can J Fish Aquat Sci 61: 360-373

> Lee CG, Farrell AP, Lotto AG, MacNutt MJ, Hinch SG, Healey MC (2003) Effects of temperature on swimming performance and oxygen consumption in adult sockeye (Oncorhynchus nerka) and coho (O. kisutch) salmon stocks. J Exp Biol 206:3239-3251

> Leung LR, Qian Y, Bin X, Washington WM, Han J, Roads JO (2004) Mid-century ensemble regional climate change scenarios for the western United States. Clim Change 62:75-113

Lichatowich HA, McIntyre JD (1987) Use of hatcheries in the management of Pacific anadromous salmonids. Am Fish Soc Symp 1:131-136

> MacNutt MJ, Hinch SG, Lee CG, Phibbs JR, Lotto AG, Healey MC, Farrell AP (2006) Temperature effects on swimming performance, energetics, and aerobic capacities of mature adult pink salmon (Oncorhynchus gorbuscha) compared with those of sockeye salmon (Oncorhynchus nerka). Can J Zool 84:88-97

Mantua N, Tohver I, Hamlet A (2010) Climate change impacts on streamflow extremes and summertime stream temperature and their possible consequences for freshwater salmon habitat in Washington State. Clim Change 102: $187-223$

Marcogliese DJ (2001) Implications of climate change for parasitism of animals in the aquatic environment. Can J Zool 79:1331-1352

Markham A (1996) Potential impacts of climate change on ecosystems: a review of implications for policymakers and conservation biologists. Clim Res 6:179-191

> McCarty JP (2001) Ecological consequences of recent climate change. Conserv Biol 15:320-331

> Mohseni O, Erickson TR, Stefan HG (1999) Sensitivity of stream temperatures in the United States to air temperatures projected under a global warming scenario. Water Resour Res 35:3723-3733

Moring W (1986) Stocking anadromous species to restore or enhance fisheries. In: Stroud RH (ed) Fish culture in fisheries management. American Fisheries Society, Bethesda, $\mathrm{MD}, \mathrm{p} 75-80$

Mote PW (2003) Trends in snow water equivalent in the Pacific Northwest and their climatic causes. Geophys Res Lett 30:1601 doi:10.1029/2003GL017258

Mote PW, Salathé EJ Jr (2010) Future climate in the Pacific Northwest. Clim Change 102:29-50

Mote PW, Parson E, Hamlet AF, Keeton WS and others (2003) Preparing for climatic change: the water, salmon, and forests of the Pacific Northwest. Clim Change 61:45-88

Mote PW, Petersen A, Reeder S, Shipman H, Whitely-Binder L (2008) Sea level rise in the coastal waters of Washington State. A report by the University of Washington Climate
Impacts Group and the Washington Department of Oceanography, Climate Impacts Group, University of Washington, Seattle, WA

Nehlsen W, Williams JE, Lichatowich JA (1991) Pacific salmon at the crossroads: stocks at risk from California, Oregon, Idaho, and Washington. Fisheries (Bethesda) 16:4-21

Parmesan C, Yohe G (2003) A globally coherent fingerprint of climate change impacts across natural systems. Nature 421:37-42

> Payne JT, Wood AW, Hamlet AF, Palmer RN, Lettenmaier DP (2004) Mitigating the effects of climate change on the water resources of the Columbia River Basin. Clim Change 62:233-256

> Perry AL, Low PJ, Ellis JR, Reynolds JD (2005) Climate change and distribution shifts in marine fishes. Science 308:1912-1915

> Pierce DW, Barnett TP, Hidalgo HG, Das T and others (2008) Attribution of declining western US snowpack to human effects. J Clim 21:6425-6444

Piper RG, McElwain IB, Orme LE, McCraren JP, Fowler LG, Leonard JR (1982) Fish hatchery management. US Fish and Wildlife Service, Washington, DC

Pörtner HO, Farrell AP (2008) Physiology and climate change. Science 322:690-692

Pörtner HO, Knust R (2007) Climate change affects marine fishes through the oxygen limitation of thermal tolerance. Science 315:95-97

> Quinn TP, Adams DJ (1996) Environmental changes affecting the migratory timing of American shad and sockeye salmon. Ecology 77:1151-1162

> Rand PS, Hinch SG, Morrison J, Foreman MGG and others (2006) Effects of river discharge, temperature, and future climates on energetics and mortality of adult migrating Fraser River sockeye salmon. Trans Am Fish Soc 135: 655-667

Randall DA, Wood RA, Bony S, Colman R and others (2007) Climate models and their evaluation. In: Solomon S, Qin D, Manning M, Miller HL (eds) Climate change 2007: the physical science basis. Contribution of working group I to the fourth Assessment Report of the Intergovernmental Panel on Climate Change. Cambridge University Press, Cambridge, p 589-662

Sala OE, Chapin FS, Armesto JJ, Berlow E and others (2000) Biodiversity-global biodiversity scenarios for the year 2100. Science 287:1770-1774

Salathé EJ Jr, Leung LR, Qian Y, Zhang Y (2010) Regional climate model projections for the State of Washington. Clim Change 102:51-75

Salinger DH, Anderson JJ (2006) Effects of water temperature and flow on adult salmon migration swim speed and delay. Trans Am Fish Soc 135:188-199

Scheuerell MD, Williams JG (2005) Forecasting climateinduced changes in the survival of Snake River spring/ summer Chinook salmon (Oncorhynchus tshawytscha). Fish Oceanogr 14:448-457

Scheuerell MD, Zabel RW, Sandford BP (2009) Relating juvenile migration timing and survival to adulthood in two species of threatened Pacific salmon (Oncorhynchus spp.). J Appl Ecol 46:983-990

$>$ Stewart IT, Cayan DR, Dettinger MD (2005) Changes toward earlier streamflow timing across western North America. J Clim 18:1136-1155

> Taylor EB (1990) Environmental correlates of life-history variation in juvenile Chinook salmon, Oncorhynchus tshawytscha (Walbaum). J Fish Biol 37:1-17

Udey LR, Fryer JL, Pilcher KS (1975) Relation of water tem- 
perature to ceratomyxis in rainbow trout (Salmo gairdneri) and Coho salmon (Oncorhynchus kisutch). J Fish Res Board Can 32:1545-1551

Unwin MJ, Quinn TP, Kinnison MT, Boustead NC (2000) Divergence in juvenile growth and life history in two recently colonized and partially isolated Chinook salmon populations. J Fish Biol 57:943-960

U.S. Fish and Wildlife Service (2009) Pacific region: fisheries program strategic plan 2009-2013. US Fish and Wildlife Service, Portland, OR

Vano JA, Scott M, Voisin N, Stöckle CO and others (2010) Climate change impacts on water management and irrigated agriculture in the Yakima River Basin, Washington, USA. Clim Change 102:287-317

Editorial responsibility: Ian Fleming, St. John's, Newfoundland, Canada
Walther GR, Post E, Convey P, Menzel A and others (2002) Ecological responses to recent climate change. Nature 416:389-395

Waples RS (1991) Genetic interactions between hatchery and wild salmonids: lessons from the Pacific Northwest. Can J Fish Aquat Sci 48:124-133

Wedemeyer GA 1996. Physiology of fish in intensive culture systems. Chapman \& Hall, New York, NY

Wiltshire KH, Manly BFJ (2004) The warming trend at Helgoland Roads, North Sea: phytoplankton response. Helgol Mar Res 58:269-273

Wood AW, Lettenmaier DP, Palmer RN (1997) Assessing climate change implications for water resources planning. Clim Change 37:203-228

Submitted: September 1, 2010; Accepted: January 25, 2011 Proofs received from author(s): February 25, 2011 